\title{
Excursions
}

Volume 7, Issue 1 (April 2017) Failure

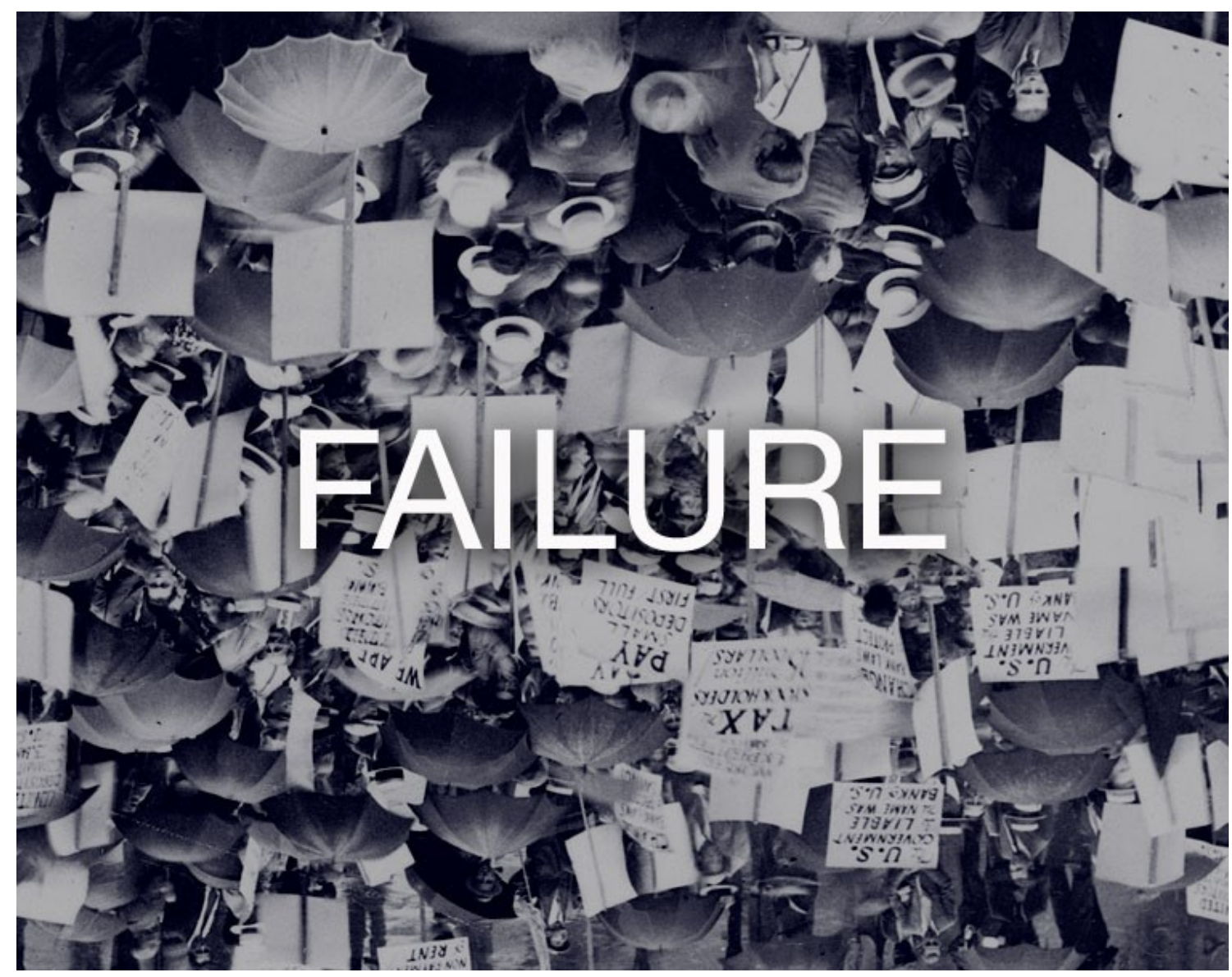

Cover photo: NY World-Telegram

Cover design: Ned Wilson Eames

Joshua G. Adair, '“Could not want a lover ... more than freedom": Failing in Sarah Waters's Affinity and Fingersmith'

Excursions, vol. 7, no. 1 (2017) 
Joshua G. Adair

Murray State University

\section{'Could not want a lover ... more than freedom': Failing in Sarah Waters's Affinity and Fingersmith}

\section{Prelude}

Sarah Waters's work troubles me; her novels seduce and repel me in nearly equal measure. I have been reading and re-reading them for over a decade now and each time I find myself wondering why works like Affinity and Fingersmith exude aggression, duplicity, and violence while daringly-and admirably, I would suggest-inserting queer women into an imagined version of the Victorian era that so completely ignored their existence. ${ }^{1}$ I find them (the stories, the queers) unruly, spiteful, and defiant-by which I mean to say I love them-and I am regularly confounded by their refusal to tell the story the liberal, progressively-minded part of me wishes to hear. They present a manner of living-or more accurately, of surviving - that resonates 
with and disconcerts me. Waters's unflattering, unresolved, even unappealing depiction of queer women in her postmodern, neo-Victorian novels routinely portrays them as cruel, conniving, crass individuals bent upon securing only their own survival, furthering their social position and power, and eschewing loyalty for all others. As a reader, at least some part of me expects otherwise; I anticipated narratives wherein sexual minorities band together in solidarity to form a community and combat the heteronormative hierarchy. And if I am completely honest, I resent Waters ever so slightly for utterly resisting that impulse to improve her characters, yet I admire her restraint. We get too many Hollywood-style, Americanised 'happy endings' these days, especially since our lived experiences rarely resemble such frippery. In the realm of neo-Victorian works like Peter Carey's Jack Maggs (1999), Michael Faber's The Crimson Petal and the White (2003), A. S. Byatt's Possession (1991), and of course, Waters's works, however, we are confronted with narratives and/or subnarratives of sexual difference and gender dissidence their authors situate in a notoriously unaccepting era, challenging readers to consider the possibilities and acknowledge queerness as a feature of all of human history. As Nadine Muller has noted,

[n]eo-Victorian fiction does not simply revisit issues such as race, sexuality, prostitution, pornography or hysteria in order to either shock or serve the current market. Instead, it engages with these themes because they present problems that are as fundamental to Western societies today as they were in the nineteenth century (2009, p.130).

In this way, Waters and her fellow neo-Victorianists foil our expectations; they force us to interrogate our problems and desires in the present by way of their representation in the past and manage to leave me, for one, feeling vaguely insecure as a result.

I have long wanted to say something about Waters, though more frequently I have wanted to shout it. I have engaged in dialogues with an 
imagined Waters wherein I demanded to know why her queer women lie to one another to such cruel effect, why they frequently perpetrate violence against one another. 'Why do none of your queer women have fathers?', I imagine demanding, and then following up with, 'does the Victorian world even matter here, aren't you just writing about the contemporary world cloaked in velvet gowns?'. I read all of the articles and interviews where scholars analyse Waters in the context of the neo-Victorian novel, their relation to Victorian criminal discourses (Gamble), intersubjectivity (Madsen), historiography (Boehm), and, of course, postmodernism (Costantini) and feminism (Kaplan), even those who investigate the architecture of Milbank (Armitt and Gamble) - all excellent, enlighteningand yet not one of them quelled the sick discomfort I frequently feel when I encounter Waters's characters Selina Dawes, Margaret Prior, Sue Trinder, and Maud Lilly, among others. As interesting and potentially academically satisfying as those investigations into the aforementioned realms of inquiry proved, I wanted an explanation for my visceral reaction. I wanted to understand my unwillingness to embrace the painful nature of Waters's construction of queerness. The answer, I argue, is that we must read Waters's novels as narratives of queer failure, rich with negative potential for scuttling normativity and dismantling schemas of queer progress.

\section{Only Connect}

Investigating my Waters problem started with E. M. Forster and found some resolution with J. Jack Halberstam. I intend this essay as literary analysis, personal essay, and proposal for a mode of reading that embraces the inherent negativity in Waters's fictions. I originally embarked on this study imagining an analysis of the texts using Marilyn R. Farwell's theories about 'spaces of sameness' as a frame for examining what I saw as a genealogy of

same-sex attraction among women rooted in a violent matriarchy capable of 
fostering, but indifferent to sustaining, same-sex desire and sex (1996). While I think the idea has merit, I also kept thinking of Maurice (1971) and Forster's insistence upon sending the titular character and his gamekeeper lover, Alec, into the Greenwood so that they might forge a life wherein their kind might be accepted and find fulfilment. I have published elsewhere about this ending and its role as a model of queer community formation, in addition to its ability to inspire subsequent authors who share a similar impulse to imagine a world that contains spaces for queer people to thrive (Adair, 2015). Forster's solution to Maurice and Alec's problem, however, I recalled, had unsettled me in a similar, if less academic, manner in my early 20s. I found it improbable and contrived; I later discovered that many critics, including Frederick McDowell (1972), Robert K. Martin (1983), and Jon Harned (1993) levelled similar criticism at the novel. In addition, as a closeted queer kid at a tiny Midwestern liberal arts college in the mid-9os, I did not thrill at the assertion that I had to abandon all society in order to secure a place for myself. Years later, I wanted to connect Waters's narrative of queer women in the Victorian era to Forster's project because I imagined each telling a version of the same story, the endgame of which was to forge an imagined space-intellectual, artistic, quasi-historical-for queer folks. The problem, as it turns out, is that both Forster's and Waters's narratives, despite their respective merits, present scenarios in which queer folk must either flee or commit criminal acts and endure/perpetrate physical and emotional violence to survive. At least I believed that was a problem; it turns out the problem was my own perspective and the lens of progress through which I was attempting to read.

Only a few pages into The Queer Art of Failure, J. Jack Halberstam convinced me that it was time to shift my frame of reference. Interrogating everything from animated films to the erotics of Nazi Germany, Halberstam forcefully argues that 
The Queer Art of Failure dismantles the logics of success and failure with which we currently live. In certain circumstances failing, losing, forgetting, unmaking, undoing, unbecoming, not knowing may in fact offer more creative, more cooperative, more surprising ways of being in the world (2011, p.2).

Could it be, I wondered, that Waters's Affinity and Fingersmith could be better understood using such a principle? I had long fought my political, and admittedly emotional, response to these novels - a response that demanded a resolution of redemption, full of progress. I wanted a model that might provide some insight into how to improve the difficulties queer people face in the contemporary world and, baselessly, I assumed that was what Waters wanted to deliver. No matter how I tried to spin the tales, though, I ended up in a world that I found ugly and treacherous, not unlike the one I currently inhabit with anti-queer 'religious freedom' legislation and hate crimes mounting each day. And yet there is also something captivating in Waters's worlds (and perhaps my own, too). Indeed, I felt I was being held captive by a mode of representation that I consider significant, one that hearkens to earlier narrative traditions about queer women wherein things end badlyfrom The Well of Loneliness to the salacious pulp novels of the 1950s like The Fear and the Guilt-but that manages to establish, perhaps even promote, a formidable agency and perseverance absent from those earlier novels wherein the characters appeared to receive retribution for their so-called aberrance. Waters's queer women endure betrayal, violence, poverty, and loneliness, among other things, but ultimately they are not destroyed or perhaps even diminished; their failure propels them forward defiantly. Prodding at the nature of failure, Halberstam asserts,

Perhaps most obviously, failure allows us to escape the punishing norms that discipline behaviour and manage human development with the goal of delivering us from unruly childhoods to orderly and predictable adulthoods. Failure preserves some of the wondrous anarchy of childhood and disturbs the supposedly clean boundaries between adults and children, winners and 
losers. And while failure certainly comes accompanied by a host of negative affects, such as disappointment, disillusionment, and despair, it also provides the opportunity to use these negative affects to poke holes in the toxic positivity of contemporary life (2011, p.3).

Using Halberstam's conception of failure, I contend that Affinity and Fingersmith, in their depictions of interpersonal violence, dysfunctional (and illegitimate) families, and unstable or unsuccessful relationships, imagine the contours of existence for queer women in the Victorian era. Interestingly, Waters manages this insertion without succumbing to the temptation to glorify, valorise, or redeem this queerness after claiming a space for it. In short, Affinity and Fingersmith claim space for queer women surviving, though not necessarily succeeding, in the Victorian era at a century's remove-valiantly proclaiming 'We exist!'-while staunchly refusing to present prettified, politically efficacious tales of them as a unified, community-minded group who are victims of a world that will not acknowledge their existence, let alone accept them. Halberstam says it best when discussing masochism and passivity, but I think his words prove just as applicable to the work of these two novels:

I refuse triumphalist accounts of gay, lesbian, and transgender history that necessarily reinvest in robust notions of success and succession. In order to inhabit the bleak territory of failure we sometimes have to write and acknowledge dark histories, histories within which the subject collaborates with rather than opposes oppressive regimes and dominant ideology (2011, p.23).

And so, ignoring the lust we have been taught to nurture for redemption, we must accept representation in the form it comes and quit squinting for, or reading in, redemption. We must stop contriving that with which we are presented. 


\section{Who's Your Daddy?}

Waters's representation of families in both Affinity and Fingersmith defies our contemporary mania for positivity to great effect. Halberstam assures us that, "[r]elieved of the obligation to keep smiling through chemotherapy or bankruptcy, the negative thinker can use the experience of failure to confront the gross inequalities of everyday life' (2011, p.4). Indeed, Waters's world affords such an opportunity by refusing to offer any explanation or justification for the existence of queer women, presenting families that would be appraised as 'broken' by virtually any standard today. Abusive mothers, non-existent fathers, and lecherous, abusive relatives unapologetically abound-no one proves trustworthy or stable in either novel-highlighting how meritless our culture's long-standing fixation upon the so-called traditional family is and refusing to offer an origin or causation narrative for the existence of queer women.

While readers may fantasise about Margaret Prior's recently deceased father and the nature of her nuclear family while it remained intact, clues abound that the home life depicted in Affinity was never the picture of idyllic Victorian domesticity. Margaret, functioning as her father's helpmeet, appears to have taken on what would have been considered a masculine role in helping with his research and writing. In his absence, she seems at once aimless and yet more free to pursue her own desire. Her mother proves intent upon managing her unwieldy daughter with the aid of drugs: 'Mother came, half an hour ago, to bring me my dose. I told her I should like to sit a little longer, that I wished she would leave the bottle with me so I might take it later-but no, she wouldn't do that. I am "not quite well enough", she said. Not "for that". Not yet' (1999, p.30). We also discover that Margaret has proven herself a failure (and a de facto criminal) by attempting to commit suicide. Finally, her family situation is further complicated by her failed romantic overtures with Helen, her love object and now sister-in-law. We learn of this now-defunct relationship early on, which sets the tone for the 
dysfunctional but physically intact Prior household when Margaret's locket goes missing:

I do not care if Ellis broke it, or if the dust-man's sweet-heart has it-she might keep the locket, though I had it from Pa. There are a thousand things, in this house, to remind me of my father. It is the curl of Helen's hair I am afraid for, that she cut from her own head and said I must keep, while she still loved me. I am only afraid of losing that-for God knows! I've lost so much of her already (1999, p.91).

The ideal middle-class Victorian family, Waters suggests through her characterisation of Margaret, never existed (even if it appeared to) and while Margaret is miserable to the point of self-destruction, alienated among but bound to her relatives, her existence as a queer woman goes unquestioned.

In Fingersmith, Sue Trinder's family exists outside Victorian respectability from the start. Throughout the course of the novel we learn that identity in this world is fluid and that Maud and Sue function somewhat interchangeably in a dizzying narrative wherein fathers appear not to exist and mothers are absent, dead, and/or masquerading as another. In this world, one's mother easily becomes another's, as with Sue and Maud, and children function as capital, as we learn from Mrs Sucksby, who declares 'I should like to farm infants' (2002, p.14). Origins and root causes prove indiscoverable here; we cannot discern the reasons for Sue's or Maud's desires or existence. Early on we encounter Sue's self-narrative about her own life:

I liked to hear them say it. Who wouldn't? But the fact is-and I don't care who knows it, now-the fact is, I was not brave at all. For to be brave about a thing like that, you must first be sorry. And how could I be sorry, for someone I never knew? I supposed it was a pity my mother had ended up hanged; but, since she was hanged, I was glad it was for something game, like murdering a miser over his plate, and not for something very wicked, like throttling a child (2002, p.12). 
For Sue and Maud both, mothers are failures, not the angelic matriarchs depicted by Coventry Patmore and so many others in the period. They are lunatics, criminals, and grifters. Those mothers-and women in generalwho seize any measure of power do so by emulating men. Muller notes, ' $[t]$ he acquisition of female agency thus replicates and reinforces the masculine system of commodification, exchange, and exploitation of women' (2009, p.119). In this world, the family-especially its women-and its environs become the site of confusion, unknowing (think of Maud with her uncle's porn collection), and fear, rather than the bastion of safety and moral rectitude so frequently cited as the Victorian achievement.

\section{Girl Fight!}

As if difficult and unstable family relationships were not enough for Waters's queer protagonists to contend with, they also face various forms of interpersonal violence-both physical and psychical-from their love objects. Facing the dissolution of her romantic attachment to Helen, her now sisterin-law, in Affinity, Margaret Prior decides to become a 'Lady Visitor' to Milbank, a prison for women inmates. Fulfilling what has become a somewhat clichéd role of the needy, wayward woman who seeks love from a prisoner, Margaret falls in love with Selina Dawes, an inmate convicted of fraud for her role as a spiritualist medium. The two hatch a plan to spring Selina from Millbank and abscond together, in an odd parody of the Forster plot of escape and renewal. Near the time of her escape, the relationship reaches its fever pitch as Selena exclaims

Oh, I could say, I love you - that is a simple thing to say, the sort of thing your sister might say to her husband. I could say that in a prison letter, four times a year. But my spirit does not love yours - it is entwined with it. Our flesh does not love: our flesh is the same, and longs to leap to itself. It must do that, 
or wither! You are like me. You have felt what it's like, to leave your life, to leave your self-to shrug it from you, like a gown (1999, p.275).

In this short passage, their relationship comes across as obsessive, even unhealthy, and we ultimately learn that it is also a ruse, just like the séances that get Dawes convicted. Selina, in cahoots with Vigers, Margaret's maid, swindles Margaret out of her personal wealth, wardrobe, and passage out of England. Selina goes so far as to steal Margaret's identity, running off with Vigers, her lover, in spiced-up Forsterian style, to live together, though not in the Greenwood. As the tale winds down, Margaret is left broken, a failure, yet, her life has meaning as she has thrown off middle-class Victorian respectability and defied social convention. She will not marry, nor will she be silenced. Her downfall leaves intact same-sex desire and the possibility of love, even if she herself proves unsuccessful at these pursuits. Vigers's final line to Selina, invoking her to '[r]emember ... whose girl you are' (1999, p.352) concludes, though it does not settle, the narrative with its unnerving proclamation of ownership and domination, suggesting that their escape will prove solely physical and that jealousy and control issues will plague the relationship.

The relationship which coheres at the end of Fingersmith suggests a slightly better chance of survival, though it boasts as great a history of failure. Switched at birth for the purpose of pulling a long con, Maud and Sue engage in a shell game of deception and interpersonal violence that results in Sue's institutionalisation at Maud and Gentleman's instigation, and Maud's captivity in Mrs Sucksby's house, all in the service of attempting to capture the fortune of her uncle, a bibliographer of pornography. About Maud we learn early on that ' $[\mathrm{t}]$ he bitch knew everything. She had been in on it from the start' (2002, p.184). Through a labyrinthine series of twists and aboutfaces, Waters weaves a tale wherein desire may exist as the sole point of potential for progress or change, though self-interest and greed frequently trample it. Even so, Sue repeatedly complicates our understanding of her 
desire, noting early on in an analysis of her response to Maud '[i]t's like you love her, I thought' (2002, p.144). Her lack of certainty suggests a failure to conceive of herself fully as same-sex attracted or to trust her own feelings, and her inner monologue further serves to complicate the nature of her feelings for Maud: '[k]issing Maud, however, was not like kissing her. It was like kissing the darkness' (2002, p.149). Safety does not exist in this world and sharing a sense of similarity, if not identity, fails to establish solidarity or common purpose. Feelings transpire as if from a distance, and are always regarded with suspicion, as though they might be masking darker, more nefarious impulses. Even witnessing Maud's sham marriage to Gentleman, not realising she was enabling her own commitment, Sue observes

I stood and held my poor, bent twig of honesty, and watched Maud standing at Gentleman's side, holding tight on to hers. I had kissed her. I had lain upon her. I had touched her with a sliding hand. I had called her a pearl. She had been kinder to me than anyone save Mrs Sucksby; and she had made me love her, when I meant only to ruin her. She was about to be married, and was frightened to death. And soon no-one would love her, ever again (2002, p.165).

Because the narrative unfolds through a series of recollections, it is difficult to know at this point whether Sue's final words-that no one would ever love Maud again-serve as a recollection of her thoughts at the time or as an assertion of her lack of love, if not a dearth of physical desire, for her.

For Maud's part, her goals seem to be always fashioned by self-interest. Her initial mission is to find a route out of her uncle's house, about whom she notes, 'to Priapus and Venus he has devoted me, as other girls are apprenticed to the needle or the loom' (2002, p.211). Once she escapes with Gentleman, who overwhelmingly demonstrates the ironic nature of his nickname, she aids in the snare that institutionalises Sue and becomes bait in the larger trap engineered by Mrs Sucksby. Surviving a byzantine elaboration of plot twists, both women manage to free themselves and Maud 
retreats to Briar to write the pornography for which her uncle had apprenticed her-a failed move by any standard of the era both because of her sex and the nature of the profession. Once she makes her escape, though, she makes no effort to seek out Sue, enacting her earlier assertion that she 'could not want a lover, more than ... freedom' (2002, p.253) and raising the spectre of the possibility that her work as a pornographer-a potentially lucrative failure-holds greater importance to her than a love match. In fact, all evidence suggests that Maud's conception of love bends toward a kind of self-obsessed sadomasochism. When defending her decision to use Sue she observes '[a]nd so you see it is love-not scorn, not malice; only love-that makes me harm her' (2002, p.302). While this assertion and her behaviour throughout the novel certainly do not suggest a cuddly, Hallmarksentimental relationship, her unconventional desire and willingness to inflict suffering upon her beloved represent a variety of love or obsession which few would laud although I suspect many have experienced. It proves difficult, I would suggest, to imagine the possibility of future safety and happiness-both in the relationship and in the larger world-because of the couple's history and their penchant for deception and violence a lá Vigers and Selina. As Muller argues, 'Maud now occupies her uncle's space, literally ... as well as symbolically. In that case, she would once again merely be imitating a masculine role, adopting rather than challenging traditional gender roles' (2009, p.123). Thus, we are left with the image of Maud writing her own sexuality, to which she grants Sue access: '[h]er silk skirts rose in a rush, then sank. She put the lamp upon the floor, spread the paper flat; and began to show me the words she had written' (2002, p.582). While access of some variety exists between the women, danger lurks still with their fidelity focused on different marks and their self-interest carefully preserved in what appear to be more fully coalesced, stereotypical gender roles at the novel's conclusion. 
The mistake in the cases of Affinity and Fingersmith is to read them as the 'triumphalist' accounts against which Halberstam inveighs. These are not great romances, nor fairy tale endings. Rather, they are depictions of various failures: pain-ridden, destructive romantic relationships; untrustworthy, manipulative families; and harsh, trap-filled communities. It is only by 'failing' in this world, by remaining single or at least self-focused, by committing crimes and betrayals, by exploiting one's self and others (even of one's own kind), that queer women may exist and stake claim to a space which previously denied their existence. The result is an unconventional narrative of survival that is about as far away from a feel-good tale as one can get: we cannot easily admire the characters, their choices, nor their destinations. The key, however, is recognising that engaging with a narrative with these goals in mind is the problem and it colours our understanding of the message. Waters provides us with characters whose lives seem real-if historically unverifiable-because they confront profound disappointment, danger, and deception. Theirs are lives we would probably never choose. These are not stories we laud as emancipatory or even flattering. Rather, they stand as a catalogue of failures gathered to demonstrate the anti-normative power of non-conformity, of the sometimes transformative power of unconventionality. Ultimately, they present marginalised people triumphant only in continuing to exist, in defying the pervasive message that they should not, especially with the methods they adopt. They are what Halberstam identifies as 'marginalized subjects':

Marginalized subjects in particular tend to be situated in an active relationship with the dilemma of betrayal, if only because normative models of citizenship situate the minoritarian subject as a kind of double agent, one who must be loyal to the nation but cannot fail to betray it. The queer and feminist dimensions of disloyalty and betrayal open onto a different kind of politics, a politics which, at various times ... comes to be associated with masochism, unbecoming, and negativity (2011, pp.163-164). 
In the end, it seems masochism, unbecoming, and negativity are all living and lively parts of contemporary queer experience, as we continue to bargain for equality-not daring to mention justice-and frequently witness the results as something far less redemptive or satisfying. Advances have been made, certainly-many cite same-sex marriage and civil unions in Western countries as the prime example of this-but we are still inundated with hatred and vitriol, which does not always transpire exclusively outside of the queer community either. One need only consider a case like that of nowconvicted murderer Elliot Morales to see the strains of Waters's worlds resting palimpsestically over our century. ${ }^{2}$ And perhaps, in the end, what they teach us is that we continue to abide in failure, violence, selfishness. To assert otherwise for the sake of positivity highlights the much larger failure at play here. Maybe it is not the Forsterian Greenwood filled with promise and potential that we need, but rather a Watersian mirror reflecting our failures to help us better recognise and interrogate ourselves. 


\section{Notes}

${ }^{1}$ For the purposes of this essay I employ the term 'queer women', rather than lesbian, to describe same-sex attracted, or least not completely heterosexual, women in Waters's work. Though Waters uses 'queer' in numerous ways which are predominantly or completely nonsexual except when interpreted through a contemporary lens (see Carroll 2006), I have adopted the term to align with Halberstam's theoretical framework throughout the essay. Carroll argues, '[i]ntegral to contemporary appropriations of the word queer is a critique of fixed categories of sexual identity, whether heterosexual or homosexual, as a means of policing and containing identity and desire. While Waters is no more unknowing about the "modern usages" of the word queer than her readers, to read queer as simply denoting lesbian would be to evacuate it of its most radical meanings' (2006, p.145). In order to capture Waters's more slippery, nebulous depiction of queer desire and existence, I have opted to forego the potentially more convenient, if less exact, 'lesbian', with its reliance upon fixed identity and opt instead for a more capacious and representative term for characters defined by their frequent indefiniteness.

${ }^{2}$ See McKinley (2016). 


\section{Bibliography}

Adair, J. G., 2015. Not satisfied with the ending: connecting The World in the Evening to Maurice. In: J. Berg and C. Freeman, eds. The American Isherwood. Minneapolis: University of Minnesota Press. pp.273-289.

Armitt, L. and Gamble, S., 2006. The Haunted Geometries of Sarah Waters' Affinity. Textual Practice. 20(1), pp.141-159.

Boehm, K., 2011. Historiography and the Material Imagination in the Novels of Sarah Waters. Studies in the Novel. 43(2), pp.237-257.

Carroll, R., 2006. Rethinking generational history: queer histories of sexuality in neo-Victorian feminist fiction. Studies in the Literary Imagination. 39(2), pp.135-147.

Costantini, M., 2006. Faux-Victorian Melodrama in the New Millennium: The Case of Sarah Waters. Critical Survey. 18(1), pp.17-24.

Farwell, M. R., 1996. Heterosexual Plots and Lesbian Narratives. New York: NYU Press.

Forster, E. M., 1971. Maurice. New York: W. W. Norton and Co.

Halberstam, J., 2011. The Queer Art of Failure. Durham, NC: Duke University Press.

Harned, J., 1993. Becoming gay in E. M. Forster's Maurice. Papers on Language and Literature. 29(1), pp.49-66.

Kaplan, C., 2008. Fingersmith's Coda: Feminism and Victorian Studies. Journal of Victorian Studies. 13(1), pp.42-55.

Llewellyn, M., 2004. “Queer? I should say it is criminal”: Sarah Waters' Affinity. Journal of Gender Studies. 13(3), pp.203-214. 
Madsen, L. H., 2013. "Remember ... Whose girl you are": Dynamics of domination in Sarah Waters' Affinity. International Journal of English Studies. 13(1), pp.149-162.

Martin, R. K., 1983. Edward Carpenter and the Double Structure of Maurice. In: S. Kellog, ed. Literary Visions of Homosexuality. New York: Harrington Press. pp.35-46.

McDowell, F., 1972. Second Thoughts on E. M. Forster's Maurice. Virginia Woolf Quarterly. 1(1), pp.46-59.

McKinley Jr., J.C., 2016. Man Testifies How Night Out in the West Village Ended With Gay Slurs and a Friend's Killing. New York Times [online]. Available at: <https://www.nytimes.com/2016/02/23/nyregion/hatecrime-trial-begins-for-2013-fatal-shooting-of-gay-man-in-westvillage.html> [Accessed 6 March 2017].

Muller. N., 2009/10. Not My Mother's Daughter: Matrilinealism, Third-wave Feminism and Neo-Victorian Fiction. Neo-Victorian Studies. 2(2), pp.109-136.

Waters, S., 1999. Affinity. New York: Riverhead Books. 2002. Fingersmith. New York: Riverhead Books. 